УДК 342.95

DOI https://doi.org/10.32844/2618-1258.2019.3-1.29

КОНОНЕЦЬ В.П.

\title{
АКТУАЛЬНІ ПИТАННЯ З НАДАННЯ АДМІНІСТРАТИВНИХ ПОСЛУГ МВС ЩОДО ВИДАЧІ СВІДОЦТВА ПРО ДОПУЩЕННЯ ТРАНСПОРТНИХ ЗАСОБІВ ДО ПЕРЕВЕЗЕННЯ НЕБЕЗПЕЧНИХ ВАНТАЖІВ
}

Наукова стаття присвячена нормативно-правовому регулюванню надання адміністративних послуг МВС щодо видачі свідоцтва про допуск транспортних засобів до перевезення певних небезпечних вантажів. Розглядається процедура, передбачена адміністративними нормами порядку, та порядок видачі свідоцтвами про допуск транспортних засобів до перевезення певних небезпечних вантажів компетентними органами. У статті розглянуто правове регулювання правових підстав використання працівниками поліції технічних засобів фотозйомки, відеозапису на підставі Закону України «Про Національну поліцію». Узагальнено матеріали Єдиного державного реєстру судових рішень щодо винесення судами судових рішень із питань використання технічних пристроїв. Розглянуто законність використання технічних засобів і надання відеодокументів як доказів у судовому процесі України. Проаналізовано питання використання відеозапису, який повинен забезпечити найбільш точну та повну фіксацію фактів, що мають доказове значення.

Стаття присвячена вивченню та обговоренню питань, пов'язаних із використанням технічного обладнання поліцією, зокрема, у процесі фото- та відеофіксації правопорушень. Вона відіграє важливу роль у пошуку злочинців, допомагає в зборі доказів, дослідженні документів та інших речових доказів. Використання відеозапису забезпечує найбільш точне та повне записування фактів, які мають доказове значення. Відеозйомка не замінює фотографію, а доповнює іiі, дає змогу знімати об'єкти не лише статикою, але й динамікою. Ось чому законодавство Іспанії щодо фото- та відеофіксації в діяльності поліції є одним із безперечних доказів під час розгляду матеріалів правопорушення в суді.

Наголошено, що погодження маршруту руху транспортних засобів під час дорожнього перевезення небезпечних вантажів здійснюється спільно з Національною поліцією України, що зумовлює погодження руху транспортних засобів конкретними вулицями та дорогами, недопущення проїзду через житлові райони, екологічно чутливі райони, промислові зони з небезпечними об'єктами або дорогами транспортних засобів; вимоги щодо руху та стоянки в разі несприятливих погодних умов, землетрусів, аварій, страйків, громадських заворушень або військових дій; обмеження руху транспортних засобів у певні дні тижня або року.

Ключові слова: видача свідоцтвва, прочесуальний порядок, послуги МВС, законодавство.

The scientific article is devoted to the normative and legal regulation of rendering of services of the Ministry of Internal Affairs concerning the issue of the certificate on the admission of vehicles to the transportation of certain dangerous goods. The procedure stipulated by the administrative norms for the procedure and the procedure for issuing a certificate of admission of vehicles to the carriage of certain dangerous goods, by the competent authorities, is considered.

The article deals with the legal regulation of the legal grounds for the use by police officers of technical means of photography, filming, video recording, on the basis of the Law of Ukraine "On the National Police". The materials of the Unified State Register

( С КОНОНЕЦЬ В.П.--кандидат юридичних наук, доцент, доцент кафедри адміністративного права, процесу та адміністратиавної діяльності (Дніпропетровський державний університет внутрішніх справ) 
of Court Decisions concerning the issuance by the courts of rulings on issues related to the use of technical devices are summarized. The legality of the use of technical means and the provision of video documents as evidence in the judicial process of Ukraine is considered. The issue of the use of video recording, which should provide the most accurate and complete fixation of facts that have probative value, is analyzed. The article is devoted to the study and discussion of issues related to the use of technical equipment by the police, in particular, in the process of photo and video fixing for offenses. She plays an important role in the search for criminals and offenders, assists in collecting evidence, exploring documents and other material evidence. The use of video recording ensures the most accurate and complete recording of facts that have probative value. Video shooting does not replace the photo, but complements it, allows you to capture objects not only in statics, but also in dynamics. That is why the legislation of Spain for photo and video fixation in the activities of the police is one of the undisputed evidence when considering the materials of the offense in court.

It is emphasized that the coordination of the route of traffic of vehicles during the road transportation of dangerous goods is carried out jointly with the National Police of Ukraine, which stipulates the coordination of the movement of vehicles with specific streets and roads, preventing passage through residential areas, environmentally sensitive areas, industrial zones with hazardous objects roads of vehicles; traffic and parking requirements in the event of inclement weather, earthquakes, crashes, strikes, public disturbances or hostilities; restricting the movement of vehicles on certain days of the week or year.

Key words: issuance of certificates, procedural order, MVD services, legislation.

Вступ. Відповідно до ст. 3 Конституції України «... людина, іiі життя і здоров’я, честь і гідність, недоторканність і безпека визнаються в Україні найвищою соціальною цінністю» [1].

У теорії окреслене питання розглядалося такими науковцями, як: С.Я. Лихова, Л.Г Мачковський, М.І. Мельник, В.О. Навроцький, Є.В. Савкін, А.В. Серебреннікова, М.І. Хавронюк, та іншими вченими-криміналістами. Дослідження цього питання адміністративістами відсутнє, що зумовлює необхідність дослідження.

Постановка завдання. Метою статті є визначення питання з надання сервісних послуг MBC щодо видачі свідоцтва про допущення транспортних засобів до перевезення визначених небезпечних вантажів.

Досягнення цієї мети передбачає вирішення таких завдань:

- вивчення особливостей надання сервісних послуг МВС щодо видачі свідоцтва про допущення транспортних засобів до перевезення визначених небезпечних вантажів;

- пошук науково обгрунтованих пропозицій і механізмів щодо покращення законодавства.

Результати дослідження. Питання, пов'язані з наданням сервісних послуг МВС щодо видачі свідоцтва про допущення транспортних засобів до перевезення визначених небезпечних вантажів, а також використанням поліцією технічних приладів, зокрема, у процесі здійснення фото- і відеофіксації, а саме - під час порушення правил дорожнього руху, є сьогодні досить актуальними. Використання технічних засобів відіграє велику роль у пошуках злочинців і правопорушників, допомагає збирати докази, досліджувати документи та інші речові докази. I тому потрібно визначити правові підстави, значимість цього питання та взагалі доречність застосування працівниками поліції цих засобів.

Відповідність конструкції спеціалізованих транспортних засобів для перевезення небезпечних вантажів вимогам ДОПНВ підтверджується шляхом видачі свідоцтва про допущення транспортних засобів до перевезення визначених небезпечних вантажів, зразок якого наведено в Додатку 2 до Правил дорожнього перевезення небезпечних вантажів, затверджених Наказом Міністерства внутрішніх справ України від 4 серпня 2018 року № 656 «Про затвердження деяких нормативно-правових актів 3 питань дорожнього перевезення небезпечних вантажів», зареєстрованим у Міністерстві юстиції України від 11 вересня 2018 року за № № 1041/32493-1043/32495 або шляхом продовження строку його дії відповідно до підрозділу 9.1.2.3 ДОПНВ.

Свідоцтво видається або продовжується сервісним центром МВС (далі - СЦ) за результатами перевірки відповідності конструкції та спеціального обладнання транспортного засобу вимогам ДОПНВ та Правил дорожнього перевезення небезпечних вантажів. 
Власник транспортного засобу, перевізник або уповноважена ним особа має право вільного вибору СЦ для проведення перевірки відповідності конструкції транспортного засобу вимогам ДОПНВ та отримання/продовження Свідоцтва. Обмеження у виборі СЦ, зокрема, від місця реєстрації транспортного засобу не допускається.

Свідоцтво видається (продовжується) на всі транспортні засоби EX/II, EX/III, FL, AT, MEMU категорій $\mathrm{N}$ та $\mathrm{O}$, які успішно пройшли обов'язковий технічний контроль, придатні до перевезення небезпечних вантажів і відповідають вимогам частини 9 ДОПНВ, які застосовуються до відповідного типу транспортних засобів з урахуванням перехідних положень, визначених у главі 1.6 та підрозділі 9.2.1.1 ДОПНВ.

Транспортні засоби, якими перевозяться небезпечні вантажі, повинні відповідати вимогам державних стандартів, безпеки, охорони праці та екології, а також у встановлених законодавством випадках мати відповідне маркування і свідоцтво про допущення до перевезення небезпечних вантажів.

Сьогодні перевізники узгоджують із Національною поліцією лише дорожнє перевезення небезпечних вантажів, які належать до вантажів підвищеної небезпеки згідно з Наказом Міністерства внутрішніх справ України «Про затвердження деяких нормативно-правових актів із питань дорожнього перевезення небезпечних вантажів» від 4 серпня 2018 року № 656 [2].

У разі дорожнього перевезення таких вантажів відповідні свідоцтва, згідно із законодавством, видаються територіальними органами Міністерства внутрішніх справ України.

Перевізник небезпечних вантажів - юридична (резидент і нерезидент) або фізична особа (громадянин України, іноземець, особа без громадянства), яка здійснює перевезення небезпечного вантажу, зобов'язаний: розробити та погодити з органами Національної поліції маршрути і режими перевезення небезпечних вантажів; забезпечити своєчасний огляд транспортних засобів територіальними органами Міністерства внутрішніх справ України та отримання відповідного свідоцтва про допуск до перевезення небезпечного вантажу; під час перевезення не відхилятися від узгодженого маршруту, додержуватися безпечних умов руху та постійно контролювати стан транспортного засобу і вантажу.

Щодо перевезень небезпечних вантажів висуваються особливі підвищені вимоги як до самого транспорту, так і до персоналу. Транспортні засоби, позначені інформаційними таблицями небезпечного вантажу, мають бути оснащені ADR-комплектами та додатковими засобами пожежогасіння. (ADR-комплект - комплект додаткового обладнання для транспортного засобу, що перевозить небезпечний вантаж). Включає всі предмети додаткового обладнання, які обов'язково повинні бути на транспортному засобі під час перевезення небезпечного вантажу згідно 3 вимогами ДОПНВ/ADR (Свропейська угода про міжнародне дорожнє перевезення небезпечних вантажів), за винятком противідкатних упорів, елементів маркування та вогнегасників [2].

Погодження маршруту руху транспортних засобів під час дорожнього перевезення небезпечних вантажів здійснюється спільно з Національною поліцією України, що зумовлює погодження руху транспортних засобів конкретними вулицями та дорогами, недопущення проїзду через житлові райони, екологічно чутливі райони, промислові зони з небезпечними об'єктами або дорогами транспортних засобів; вимоги щодо руху та стоянки в разі несприятливих погодних умов, землетрусів, аварій, страйків, громадських заворушень або військових дій; обмеження руху транспортних засобів у певні дні тижня або року.

Проаналізувавши дані з Єдиного державного реєстру судових рішень, хочу зазначити, що здебільшого, коли витримана процедура застосування відеозйомки правопорушення, є незрозумілою позиція суду, чому саме в порядку ст. 251 КУпАП [5] відеозапис не є доказом? Чому суд не завжди сприймає запис із відеореєстратора як явний факт вчиненого правопорушення, що не потребує додаткової та більшої доказової бази? Насамперед хочеться зауважити, що це є досить складним явищем у судовій діяльності, адже важко однозначно стверджувати взагалі, на яких підставах суд приймає те чи інше рішення, не завжди дотримуючись норм КУпАП. На мою думку, суд під час вирішення справи, а саме - винесення вироку, враховує свої власні переконання щодо цієї справи та діє відповідно до ситуації, що склалася. Тим більше хочу зауважити, що цей факт не $є$ з правового погляду правильним, тому що не відповідає саме таким вимогам, як неупередженість та об'єктивність. Тому для розкриття проблематики з приводу розгляду судами адміністративних справ у частині залучення доказової бази фото- та відеофіксації доцільно розглянути низку винесених постанов судом. Оскільки якщо звернутися до статистики оскарження винесених рішень за ст. 130 КУпАП, то стан ії залишається незрозумілим і постійно змінюється, але зріст все одно вбачається. 
Враховуючи різноманітний характер і вибраний напрям до проведення суддею судового розгляду, слід зауважити на тому, що вибраний шлях, безперечно, впливає на хід і результати процесу в суді. Найчастіше у вироках чи інших рішеннях суду вбачається неоднозначність під час задоволення чи відмови залучення як доказів результатів фото- чи відеозйомки. В одному випадку у разі відсутності такого виду доказу суддя витребовує залучення або виїмку такого запису, що, власне, затягує час проведення судового процесу. А в інших - навпаки, за наявності необхідного відео заперечує їхній доказовий характер і взагалі відхиляє можливість долучити до справи. Така позиція суддів дуже неоднозначна, незрозуміла і потребує детального вивчення із наукового та практичного поглядів і надалі з формуванням і затвердженням інструкції щодо визначення алгоритму дій під час оцінки відеодоказів для різних категорій справ з урахуванням усіх важливих аспектів, оскільки в окремих випадках допустимість відеозапису може роз'яснити та прискорити розгляд справи із справедливим і законним винесенням вироку судом. За відсутності відповідного носія доказу судовий розгляд може зайти в глухий кут, а в гіршому разі - притягнути до відповідальності невинну особу, що нині трапляється досить таки часто.

Дослідивши Постанову апеляиійного суду по справі за № 490/11314/16-n від 24 лютого 2017 р. в м. Миколаїв, хочу акцентувати увагу на тому факті, що суб'єктом вчинення правопорушення є волонтер АТО Степан Панчук, який, перебуваючи у стані алкогольного сп’яніння, двічі був зупинений працівниками поліції.

За результатом першого судового розгляду суд виніс рішення не на користь волонтера, а таке: «... Визнати винним у вчиненні адміністративного правопорушення, передбаченого ч. $1 \mathrm{~cm} .130 \mathrm{KУпАП,} \mathrm{та} \mathrm{накласти} \mathrm{адміністративне} \mathrm{стягнення} \mathrm{у} \mathrm{виді} \mathrm{шттрафу} \mathrm{у} \mathrm{розмірі} 600$ неоподаткованих мінімумів доходів громадян, щяо становить 10200 /десять тисяч двісті/ гривень із позбавлення права керування транспортними засобами строком на 1 /один/ рік. Стягнути з ОСОБА_1 судовий збір у розмірі 320 грн. 00 коп. в дохід держави. У клопотанні громадськоі організачїї «УЧАСНИКІВ БОЙОВИХ ДІЙ ОСОБА_4 ОСОБА_2» про передачу матеріалів у справі про притягнення ОСОБА_1 до адміністративної відповідальності за ч. $1 \mathrm{~cm} .130 \mathrm{KУnАП} \mathrm{на}$ розгляд громадської організаиії «УЧАСНИКІВ БОЙОВИХ ДІЙ ОСОБА_4 ОСОБА_2»-відмовиmи». Але не все так гарно, як здавалося на перший погляд, за результатами розгляду апеляційного подання суд усе ж таки звільнив цю особу від відповідальності: «... Заслухавщи пояснення ОСОБА_1, дослідивши матеріали справи, враховуючи обставини адміністративного правопорушення, характер вчиненого правопорушення та дані про особу, який у вчиненому шџиро розкаявся, позитивно характеризується громадською організаиією, а також його заняття волонтерською діяльністю, з урахуванням характеру вчиненого правопорушення і особи правопорушника, вважаю за доцільне звільнити його від адміністративної відповідальності та застосувати до нього захід громадського впливу... Передати матеріали справи про притягнення ОСОБА_1 до адміністративної відповідальності за ч. $1 \mathrm{~cm} .130,4.1 \mathrm{~cm} .130$ КУпАП на розгляд громадської організації "Всеукраӥнський союз ветеранів АТО», ще за адресою - м. Пустомити, вул. Кандиби, 5/6. Провадження по справі про притягнення до адміністративної відповідальності ОСОБА_1-закрити»[3].

Причиною того можна вважати внесення змін до ст. 130 КУПАП, а саме: оскільки за керування автомобілем у стані сп'яніння одразу передбачене позбавлення права керування строком на 1 рік, то є сенс оскаржувати протоколи патрульної поліції, винесені за ч. 1 ст. 130 КУпАП та постанови судів про притягнення особи до відповідальності за вказаною статтею [4].

Отже, якщо повернутися до аналізу вироків, можна дійти висновку, що є дві причини, за яких суд задовольняє оскарження в повному обсязі - незаконність складення протоколу та клопотання про призначення експертизи відеозапису поліцейських.

Висновки. Для вирішення цієї проблеми прозорості надання адміністративних послуг MBC щодо видачі свідоцтва про допущення транспортних засобів до перевезення вантажів необхідно врегулювати питання щодо ефективності та оперативності роботи національної автоматизованої інформаційної системи, яка досить часто працює з перебоями, та ввести низку нововведень. Зокрема, підвищити кошторис послуги на отримання свідоцтва про допущення транспортних засобів до перевезення вантажів, оскільки висока ціна має відбити бажання у громадян вступати в корупційні зв'язки для отримання такого свідоцтва. Складання теорії і практики має супроводжувати відеозйомка із кількох камер. Інформація про те, хто, коли і кому видав медичну довідку та водійське посвідчення, має бути або публічною, або доступною певним колам осіб. Поліціянти, що приймають іспити, мають отримувати гідну зарплату для зменшення корупційних ризиків у сфері надання адміністративних послуг МВС. 


\section{Список використаних джерел:}

1.Конституція України. Відомості Верховної Ради України (ВВР). 1996. № 30. Ст. 141. https://zakon.rada.gov.ua/laws/show/254\%D0\%BA/96-\%D0\%B2\%D1\%80.

2.Оскарження постанови по ст. 130 КУпAП. URL: http://pravova-rada.com/ua/ 296-obzhalovanie-postanovlenija-po-st-130-kuoap.

3.Наказ Міністерства внутрішніх справ України «Про затвердження деяких нормативно-правових актів 3 питань дорожнього перевезення небезпечних вантажів» від 4 серпня 2018 р. № 656 .

4.Наказ Департаменту патрульної поліції НПУ від 3 лютого 2016 р. № 100, яким затверджено «Інструкцію про порядок зберігання, видачі, приймання, використання нагрудних відеокамер (відеореєстраторів) працівниками патрульної поліції та доступ до відеозаписів 3 них».

5.Наказ Департаменту патрульної поліції НПУ від 24 листопада 2015 р. № 14/1 «Про порядок зберігання, використання відеозапису з відеореєстраторів патрульних».

6.Про Національну поліцію : Закон України від 2 липня 2015 р. № 580-VIII. URL: htpp//zakon1.rada.gov.ua.http://zakon4.rada.gov.ua/laws/show/580-19.

УДК 351.741:3.082

DOI https://doi.org/10.32844/2618-1258.2019.3-1.30

КУЗЬМЕНКО І.Г.

\section{НОРМАТИВНО-ПРАВОВЕ РЕГУЛЮВАННЯ ПРОФЕСІЙНОЇ ПІДГОТОВКИ УПРАВЛІНСЬКИХ КАДРІВ ПОЛЦЦЇ КРАЇН ЄС}

У статті проаналізовано досвід організації професійної підготовки управлінських кадрів поліції країн ЄС. Сформовано висновки щодо можливості його використання в удосконаленні системи адміністративно-правового забезпечення професійної підготовки керівних кадрів Національної поліції України. Наголошено, що в європейських країнах систему державного управління у сфері освіти щодо підготовки персоналу для правоохоронних органів утворюють загальнонаціональні (федеральні) закони про поліцію, декрети і укази глав держав і керівників виконавчої влади, а також нормативні акти органів місцевого самоврядування, які містять положення про правовий режим окремих категорій поліцейського персоналу. 3'ясовано, що система освітніх установ поліції Великої Британії представлена навчальними центрами, що здійснюють початкову підготовку й підвищення кваліфікації констеблів, сержантів, детективів для регіональних служб поліції (усього їх вісім), навчальними центрами з підготовки співробітників спеціальних підрозділів (підрозділів із боротьби з масовими безпорядками й збройних спеціальних загонів поліціі), а також єдиним загальнонаціональним центром із підготовки керівних кадрів поліції - Брамшилль. Визначено, що визначальну роль в організаційному й нормативному регулюванні професійної підготовки управлінських кадрів поліції відіграє організаційно-структурна побудова правоохоронних органів, рівень їхньої централізації або децентралізації, а також їхня компетенція і підвідомчість, а відповідно, і підвідомчість систем професійної підготовки. Зроблено висновок, що європейські системи професійної підготовки управлінських кадрів поліції встановлюють характерну тенденцію, яка полягає в уніфікації національних законодавств, функціональних повноважень і завдань професійного навчання персоналу. В сучасних умовах сьогодення загрози у правоохоронній сфері спонукають до розширення формату співпраці співробітників управлінських кадрів поліції, громад-

КУЗЬМЕНКО І.Г. - ад’юнкт кафедри публічного управління та адміністрування (Національна академія внутрішніх справ) 